\title{
Differences in the Attitudes of Fourth Grade Pupils of the Elementary School According to the Teaching of Physical Education in Terms of Gender
}

\author{
Katarina Dragutinovic ${ }^{1}$, Milena Mitrovic ${ }^{1}$ \\ 'University of Montenegro, Faculty for Sport and Physical Education, Niksic, Montenegro
}

\begin{abstract}
The main aim of this research was to determine the differences in attitudes between boys and girls of the fourth grade towards the continuation of physical education. The sample of respondents was 121 pupil of the elementary school "Vuk Karadžić" from Podgorica. Students are divided into 2 sub-samples according to the gender criterium (74 boys, 47 girls). We used an anonymous standardized questionnaire adapted to this research. The results were processed descriptively and tabulated. A H2 test was used to determine statistically significant differences. The results showed that differences between boys and girls appear only in favorite sports, while in other issues there are no statistically significant differences.
\end{abstract}

Key words: Attitudes, Differences, Pupils, Fourth Grade

\section{Uvod}

Fizičko vaspitanje je specifično vaspitno područje, koje doprinosi razvoju čovjeka u cjelini. To nije samo podsticanje rasta i razvoja, razvijanje tjelesnih sposobnosti i unapređenje zdravlja, već i znalačko korišćenje sistema fizičkih vježbi, igara i sportova, kojima se utiče na cjelokupni razvoj čovjeka (Jovanović, 1998). Kao takvo, predstavlja veoma bitnu komponentu psiho-fizičkog razvitka i zdravlja djeteta (Branković i Ilić, 2003). Iz navedenih razloga, nastavu fizičkog vaspitanja je potrebno sprovoditi kvalitetno, artikulisano i sistematski. Za sprovođenje kvalitetne nastave neophodne su materijalni uslovi, kao i kompetentni nastavnici, koji bi trebalo da podstiču pozitivne stavove učenika prema nastavi fizičkog vaspitanja. Stav je jedan od osnovnih pojmova za razumijevanje društvenog života, te jedan od osnovnih pojmova socijalne psihologije uopšte (Pennington, 1997). Da bi lakše odredili svoj odnos prema velikom broju različitih pojava, te adekvatno reagovali na njih, ljudi formiraju stavove. Naime, stavovi nam omogućavaju da steknemo fiksirane standarde za svoje prosuđivanje i svoje postupke. Na taj način lakše ocjenjujemo i klasifikujemo objekte i situacije što nam omogućava lakše i brže snalaženje i djelovanje. Stavovi predstavljaju trajnu tendenciju da se prema nekom objektu reaguje na određeni, pozitivan ili negativan način (Rot, 1983). Dakle, kako bi učenici imali normalan psiho-fizički razvoj, neophodno je da razviju pozitivne stavove prema nastavi fizičkog vaspitanja.

Kad su u pitanju razlike u stavovima među polovima, prethodna istraživanja su pokazala da postoje razlike između dječaka i djevojčica prema nastavi fizičkog vaspitanja i fizičkog vježbanja uopšte (Đorđić, 2006; Rowland, 1999). Ovo upućuje na činjenicu da su djevojčice manje fizičke aktivne. Takođe, brojna istraživanja pokazuju da fizičko vaspitanje može biti pogodno za podsticanje rodnih stereotipa i da nastavna praksa ne izlazi u susret specifičnim potrebama i afinitetima djevojčica (Đorđić i Tumin, 2008). Tako, dječaci mlađeg školskog uzrasta se više bave fudbalom ili nekim drugim sportom koji su zastupljeniji u nastavi fizičkog vaspitanja, dok djevojčice biraju plesove ili neke elementarne igre koje su manje aktivne i manje zastupljene u nastavi.

Cilj našeg istraživanja je upravo ispitati stavove učenika 4. razreda osnovne škole prema nastavi fizičkog vaspitanja, kako bi utvrdili da li postoje razlike u stavovima s obzirom na pol.

Correspondence:

Montenegro

sport

\section{K. Dragutinovic}

University of Montenegro, Faculty for Sport and Physical Education, Niksic, Montenegro

E-mail: katarinadragutinovic24@gmail.com 


\section{Metod}

Uzorak ispitanika u istraživanju činio je 121 učenik (9-10 godina) 4. razreda OŠ „Vuk Karadžićc iz Podgorice. Ispitanici su podijeljeni u dva subuzorka prema kriterijumu pola, pri čemu su jedan uzorak činili dječaci $(n=74)$ i drugi djevojčice $(n=47)$. Podaci o uzorku su brojčano i procentualno prikazani u Tabeli 1.

U istraživanju je korišćen anonimni standardizovani upitnik
(Dzibric, Dedic, \& Bojic, 2011) koji je modifikovan i prilagođen istraživanju. Nakon pregleda upitnika, iz istraživanja su isključeni nepotpuno i nejasno popunjeni. Rezultati su prikazani tabelarno (u procentima) i deskriptivno. Statistički značajne razlike u varijablama s obzirom na pol utvrđene su H2 (HI kvadrat) testom na nivou značajnosti od $\mathrm{p}<0.05$.

Tabela 1. Brojčana i procentualna zastupljenost „X" nogu i značajnost razlika po polu.

\begin{tabular}{ccc}
\hline Dječaci & Djevojčice & Ukupno \\
\hline $74(61.0 \%)$ & $47(39.0 \%)$ & $121(100.0 \%)$ \\
\hline
\end{tabular}

\section{Rezultati}

Podaci koji su dobijeni ovim istraživanjem prikazani su u tabelama (Tabela 2 i Tabela 3), odvojeno za dječake i djevojčice istog uzrasta. Vrijednosti dobijenih odgovora za svako pitanje iskazane su brojčano i procentualno.

Posmatrajući Tabelu 2, na osnovu datih odgovora na prvo pitanje, vidimo da većina dječaka ( $80 \%$ ) ovog uzrasta ima pozitivan stav prema nastavi fizičkog vaspitanja. Ostatak ima negativan stav i sa nezadovoljstvom prisustvuje nastavi (20\%).

Prilikom odgovaranja na drugo pitanje, dječaci su imali mogućnost da odaberu šta to najviše vole da rade na časovima fizičkog vaspitanja. Više od pola učenika se opredijelilo za igre sa loptom (53\%), za vježbe (32\%), a najmanji procenat je odabrao trčanje (14\%). Zadovoljstvo nastavom u njihovoj školi iskazano je velikim procentom (93\%). Neznatan broj njih bio djelimično zadovoljan (4\%) i nezadovoljan (3\%).

Tabela 2. Stavovi dječaka IV razreda o fizičkom vaspitanju

\begin{tabular}{|c|c|c|c|}
\hline Pitanja & Odgovori & Broj & Procenat (\%) \\
\hline \multirow{2}{*}{ 1. Da li sa zadovoljstvom odlaziš na časove fizičkog vaspitanja? } & a) $\mathrm{Da}$ & 59 & 80 \\
\hline & b) $\mathrm{Ne}$ & 15 & 20 \\
\hline \multirow{3}{*}{ 2. Šta najviše voliš da radiš na časovima fizičkog vaspitanja? } & a) Trčim & 10 & 13 \\
\hline & b) Igram igre & 39 & 53 \\
\hline & c) Vježbam & 24 & 34 \\
\hline \multirow{3}{*}{ 3. Da li ste zadovoljni nastavom fizičkog vaspitanja u vašoj školi? } & a) Potpuno & 69 & 93 \\
\hline & b) Djelimično & 3 & 4 \\
\hline & c) Nezadovoljan sam & 2 & 3 \\
\hline \multirow{3}{*}{$\begin{array}{l}\text { 4. Da li vježbanje i igranje na časovima fizičkog vaspitanja pozitiv- } \\
\text { no utiče na zdravstveno stanje i razvitak učenika? }\end{array}$} & a) Koristi zdravlju & 68 & 92 \\
\hline & b) Ne koristi zdravlju & 3 & 4 \\
\hline & c) Šteti zdravlju & 3 & 4 \\
\hline \multirow{2}{*}{ 5. Da li bi više volio/voljela da imaš? } & $\begin{array}{l}\text { a) Lijepo i moderno } \\
\text { odijelo }\end{array}$ & 10 & 14 \\
\hline & $\begin{array}{l}\text { b) Zdravo i razvijeno } \\
\text { tijelo }\end{array}$ & 64 & 86 \\
\hline \multirow{3}{*}{ 6. Šta je za učenika najbolje? } & a) Da pravilno igra & 27 & 36 \\
\hline & $\begin{array}{l}\text { b) Da rješava zadatke } \\
\text { iz matematike }\end{array}$ & 10 & 14 \\
\hline & c) I jedno i drugo & 37 & 50 \\
\hline \multirow{3}{*}{ 7. Od igara koje imamo meni se posebno dopadaju? } & a) Igre u učionici & 4 & 5 \\
\hline & b) Igre u dvorištu & 9 & 12 \\
\hline & c) Igre u sali & 61 & 83 \\
\hline \multirow{3}{*}{$\begin{array}{l}\text { 8. Kada bi ste bili u prilici da nešto mijenjate u nastavi fizičkog } \\
\text { vaspitanja, mijenjali bi ste? }\end{array}$} & a) Ništa & 60 & 81 \\
\hline & b) Uslove & 2 & 2 \\
\hline & c) Program & 12 & 16 \\
\hline
\end{tabular}

Svijest o tome koliko nastava fizičkog vaspitanja važna za razvitak i zdrastveni status učenika, potvrđuje se odgovorima datim na četvrtom pitanju, gdje je $92 \%$ odgovorilo da ona doprinosi zdravlju. Takođe, i ovom slučaju bio je mali procenat dječaka koji su odgovorili da ne doprinosi zdravlju (4\%), pa čak i da mu škodi
(4\%). Odgovorom na peto pitanje iz upitnika, učenici su jasno stavili do znanja da postoji korelacija između četvrtog i petog pitanja, odnosno da zdravlje i razvoj imaju izraženo mjesto kod učenika ovog uzrasta. Tako je njih $86 \%$ odgovorilo da želi zdravo i razvijeno tijelo, dok je $14 \%$ odgovorilo da bi želi moderno odijelo. 
Učenici su bili podijeljeni prilikom izražavanja stava o tome šta je od predmeta važnije u školi: 50\% njih se odpredijelilo da je podjednako važno znati matematiku i fizičko vaspitanje, ali ipak se pri odabiru više njih odlučilo igru i poštovanje njenih pravila $36 \%$, a $14 \%$ za pravilno rješavanje zadataka iz matematike.

$\mathrm{Na}$ osnovu dobijenih odgovora na pitanje br. 7, uočavamo da je prostor zaista jedan od najvažnijih faktora prilikom organizovanja i sprovođenja nastave fizičko vaspitanja. Jasan je stav dječaka ovog uzrasta, najviše vole igre u sali (83\%), zatim igre u dvorištu (12\%) i veoma mali procenat njih voli sprovođenje ove nastave $\mathrm{u}$ učionici (5\%). Koliko su zaista zadovoljni nastavom potvrđuje i završno pitanje, gdje $81 \%$ ne bi ništa mijenjalo u nastavi, ostatak bi promijenio program (16\%) i uslove (3\%).

Učenice su prilikom popunjavanja ovog upitnika (Tabela 3), već na početku iskazale pozitivan stav prema nastavi fizičkog vaspitanja. Na prvom pitanju je $89 \%$ njih odgovorilo da sa zadovoljstvom odlazi na ove časove. Dok su mišljenja bila prilično podijeljena na drugom pitanju, gdje su djevojčice morale da se odluče ono šta najviše vole na časovima fizičkog vaspitanja, pa su procenti za sve tri mogućnosti bili veoma bliski. Igre su i kod djevojčica imale najveći uticaj (45\%), zatim vježbe (32\%) i trčanje (23\%). One su svojim odgovorima na trećem pitanju iskazale zadovoljstvo nastavom fizičkog vaspitanja u školi, preovladali su odgovori potpuno (85\%), dok su djelimično (11\%) i nezadovoljne (4\%).

Koliko su djevojčice ovog uzrasta upućene u to koliko nastava fizičkog vaspitanja doprinosi zdravlju, govori u prilog to što je $89 \%$ njih odgovorilo pozitivno. Mali je procenat onih koje nisu upućene u to (11\%), ali odgovorom na peto pitanje kompletan uzorak je dao odgovor koji potvrđuje da je zdravlje ovom uzrastu na važnom mestu (100\%).

Tabela 3. Stavovi djevojčica IV razreda o Fizičkom vaspitanju

\begin{tabular}{|c|c|c|c|}
\hline Pitanja & Odgovori & Broj & Procenat (\%) \\
\hline \multirow{2}{*}{ 1. Da li sa zadovoljstvom odlaziš na časove fizičkog vaspitanja? } & a) $\mathrm{Da}$ & 42 & 89 \\
\hline & b) $\mathrm{Ne}$ & 5 & 11 \\
\hline \multirow{3}{*}{ 2. Šta najviše voliš da radiš na časovima fizičkog vaspitanja? } & a) Trčim & 11 & 23 \\
\hline & b) Igram igre & 21 & 45 \\
\hline & c) Vježbam & 15 & 32 \\
\hline \multirow{3}{*}{ 3. Da li ste zadovoljni nastavom fizičkog vaspitanja u vašoj školi? } & a) Potpuno & 40 & 85 \\
\hline & b) Djelimično & 5 & 11 \\
\hline & c) Nezadovoljan sam & 2 & 4 \\
\hline \multirow{3}{*}{$\begin{array}{l}\text { 4. Da li vježbanje i igranje na časovima fizičkog vaspitanja pozitiv- } \\
\text { no utiče na zdravstveno stanje i razvitak učenika? }\end{array}$} & a) Koristi zdravlju & 42 & 89 \\
\hline & b) Ne koristi zdravlju & 5 & 11 \\
\hline & c) Šteti zdravlju & 0 & 0 \\
\hline \multirow{2}{*}{ 5. Da li bi više volio/voljela da imaš? } & $\begin{array}{l}\text { a) Lijepo i moderno } \\
\text { odijelo }\end{array}$ & 0 & 0 \\
\hline & $\begin{array}{l}\text { b) Zdravo i razvijeno } \\
\text { tijelo }\end{array}$ & 47 & 100 \\
\hline \multirow{3}{*}{ 6. Šta je za učenika najbolje? } & a) Da pravilno igra & 6 & 13 \\
\hline & $\begin{array}{l}\text { b) Da rješava zadatke } \\
\text { iz matematike }\end{array}$ & 1 & 2 \\
\hline & c) I jedno i drugo & 40 & 85 \\
\hline \multirow{3}{*}{ 7. Od igara koje imamo meni se posebno dopadaju? } & a) Igre u učionici & 0 & 0 \\
\hline & b) Igre u dvorištu & 0 & 0 \\
\hline & c) Igre u sali & 47 & 100 \\
\hline \multirow{3}{*}{$\begin{array}{l}\text { 8. Kada bi ste bili u prilici da nešto mijenjate u nastavi fizičkog } \\
\text { vaspitanja, mijenjali bi ste? }\end{array}$} & a) Ništa & 42 & 89 \\
\hline & b) Uslove & 1 & 2 \\
\hline & c) Program & 4 & 9 \\
\hline
\end{tabular}

Kada je u pitanju izbor između važnosti matematike i fizičkog vaspitanja, djevojčice su jasno stavile do znanja da su oba predmeta jako važna, bez odvajanja (85\%). Čak je više procenata, kod biranju između jednog od ta dva predmeta, pridalo veću važnost igri (13\%), nego rješavanju zadataka (2\%). Jednoglasne su bile i prilikom odabira prostora za izvođenje nastave, a to je fiskulturna sala (100\%).

Pozitivan stav i zadovoljstvo prema nastavi fizičkog vaspitanja, potvrdilo se i kod njih kada je u pitanju posljednje pitanje. Većina učenica (89\%) ne bi mijenjale ništa, dok bi $9 \%$ njih mijenjale program i $2 \%$ uslove. 
Uvidom u upoređivanje stavova dječaka i djevojčica o nastavi fizičkog vaspitanja (Tabela 4), nakon sprovedenog Hi kvadrat testa, primjećujemo da se statistički značajne razlike javljaju u određenim varijablama. Razlike se javljaju u stavovima prema važnosti lijepog oblačenja i zdravog tijela $i$ to $u$ korist djevojčica, gdje $100 \%$ njih smatra da je važnije imati zdravo tijelo, dok je kod dječaka taj procenat manji i iznosi $86.49 \%$. Takođe, razlike se javljaju i u varijabli u kojoj je pro- cjenjivano da li je za učenike važnije da pravilno igraju ili da rješavaju zadatke, takođe u korist djevojčica, gdje većina smatra da je podjednako važno i jedno i drugo. Statistički značajne razlike se javljaju i u varijabli za procjenu najboljeg prostornog ambijenta za igru, takođe u korist djevojčica, koje smatraju da je školska sala najpogodnija za održavanje nastave fizičkog vaspitanja.

Tabela 4. Dobijene vrijednosti Hi kvadrat testa koje pokazuju razliku među subuzorcima (1-dječaci, 2-djevojčice)

\begin{tabular}{clc}
\hline \multicolumn{2}{l}{ Varijable } & Sig. \\
\hline 1. & Da li sa zadovoljstvom odlaziš na časove fizičkog vaspitanja? & .164 \\
2. & Šta najviše voliš da radiš na časovima fizičkog vaspitanja? & .364 \\
3. & Da li ste zadovoljni nastavnom fizičkog vaspitanja u vašoj školi? & .316 \\
4. & Da li vježbanje i igranje na časovima fizičkog vaspitanja pozitivno utiče na zdravstveno & .149 \\
5. & Danje i razvitak učenika? & .009 \\
6. & Šta je za učenika najbolje? & .000 \\
7. & Od igara koje imamo meni se posebno dopadaju: & .010 \\
8. & Kada bi ste bili u prilici da nešto mijenjate u nastavi fizičkog vaspitanja, mijenjali bi ste? & .058 \\
\hline
\end{tabular}

Legenda: Sig. - Značajnost razlike Hi kvadrat testa

\section{Diskusija}

Imajući u vidu koliko su stavovi učenika presudni kada je u pitanju sama angažovanost $\mathrm{u}$ nastavi fizičkog vaspitanja, jasno je koliko nam je potreban uvid i spoznaja istih. Tu presudnu ulogu imaju sadržaji i organizacija nastave koji trebaju biti prilagođeni afinitetima učenika.

Dobijeni rezultati ovog istraživanja ukazuju na pozitivne stavove učenika prema nastavi fizičkog vaspitanja. Ono što je značajno, jeste da su djeca svjesna važnosti ove nastave za pravilan razvoj i zdravlje, pa odatle i proističu pozitivni stavovi. Sam proces organizovanja nastave, kao i prostora gdje se ista odvija, ima takođe veliki doprinos pri formiranju ovakvih stavova. Djevojčice su datim odgovorima na prvo pitanje pokazale da sa zadovoljstvom odlaze na nastavu fizičkog vaspitanja (89\%), dok su dječaci isto to pokazali, ali u nešto manjem procentu (80\%). Pošto su dječaci ti koji su držali primat kada je u pitanju želja za dokazivanjem sposobnosti na ovim časovima, pretpostavlja se da je možda sam program i organizacija nastave dovela do ovakvog rezultata. Međutim, ono što je pozitivno, jeste da su djevojčice, koje su dosad pokazivale nezainteresovanost i stidljivost prema ovoj nastavi sa manjim procentom zadovoljstva (E. Međedović, Murić, i A. Međedović, 2005), sada pokazale bolje rezultate.

Prilikom odabira sadržaja na časovima fizičkog vaspitanja, većina anketiranih učenika (85\%) i učenica (77\%) se odlučila za elementarne igre i vježbanje, dok je najmanji procenat u oba slučaja odabrao trčanje. Ovo je jako dobro, zato što su time pokazali da ipak djeca više vole kada imaju određeni cilj pri radu, a ne samo želju za trošenjem energije. Ovo je važan indikator zrelosti djece ovog uzrasta, i poruka nastavnicima da ipak energiju žele da troše u skladu sa postavljenim ciljem. O tome koliko su zadovoljni časovima fizičkog vaspitanja u školi, jasno su stavili do znanja odgovorima, pa je većina učenika (93\%) i učenica (85\%) u potpunosti zadovoljno. Ipak, i pored ovako velikih procenata moramo se osvrnuti na onih 7\%, koji su iskazali nezadovoljstvo nastavom fizičkog vaspitanja. Ovo se može povezati sa uslovima u kojima se časovi održavaju, opremljenost rekvizitima ili sadržajima koji ne odgovaraju svi- ma jednako. Svakako, za to je potrebno dodatno istraživanje sa ponuđenim odgovorima koji bi mogli pružiti odgovore za ove nedoumice.

Svijest o tome koliko nastava fizičkog vaspitanja važna za razvitak i zdrastveni status učenika, potvrđuje se odgovorima datim na četvrtom pitanju. Čak $92 \%$ učenika i $89 \%$ učenica je odgovorilo da fizičko vaspitanje koristi zdravlju, i time pokazali da su upućeni u dobrobiti koje im ovaj nastavni predmet donosi ukoliko se rad odvija na pravilan način. Procenat koji je neupućen u ovu problematiku je $15 \%$ kod oba pola zajedno, a samo kod dječaka postoje odgovori da šteti zdravlju (4\%). Ovo je moguće korigovati objašnjenjem nastavnika zašto je fizičko vježbanje važno našem zdravlju. Takođe, prilikom demonstracije vježbi, potrebno je ukazivati kako ona utiče na poboljšanje psiho-fizičkog razvoja djeteta. Da učenici znaju koliko je važno zdravlje i pravilan razvoj tijela, dokazano je odgovorima na peto pitanje gdje su učenici $(86 \%)$ i učenice $(100 \%)$ odgovorili da je važnije imati zdravo tijelo. Međutim, s obzirom na veliki procenat pozitivnih odgovora kod učenica, u ovoj varijabli, javljaju se statistički značajne razlike u stavovima između dječaka i djevojčica, i to u korist djevojčica.

Često se u školovanju javlja velika dilema kod učenika i roditelja, a ona se odnosi na to koji je zapravo predmet najvažniji. Većina se opredjeljuje za matematiku, uglavnom zbog predrasuda da je ona teška pa joj pridaju veliku važnost. Ovim pitanjem se željelo utvrditi šta o tome misle učenici i da li su kod njih drugačiji stavovi, jer ipak je zdravlje nešto što je osnov za postizanje uspjeha na svim poljima (Mišigoj-Duraković, 1999). Na osnovu rezultata koji su dobijeni ovim istraživanjem vidimo da je $50 \%$ učenika imalo stav da su podjednako važna oba predmeta, dok je kod učenica taj procenat bio veći (85\%). $\mathrm{Na}$ osnovu rezultata Hi kvadrat testa, zaključujemo da se i u ovoj varijabli javljaju statistički značajne razlike u korist djevojčica, s obzirom na veći procenat onih koji smatraju da su jednako važna oba predmeta. Međutim, kako kod učenica, tako i kod učenika kod je u pitanju odabir između ova dva predmeta prednost ima fizičko vaspitanje (49\%) nad matematikom (13\%). Ovo je na neki način opovrgnulo stavove koji su bili 
zastupljeni godinama unazad i samim tim stavljale vještine u drugi plan kada je u pitanju školovanje (Vidić, 2016).

Koliko je važan prostor i uslovi za izvođenje nastave pokazuje činjenica da se većina odlučila za izvođenje nastave u fiskulturnoj sali, gdje se nalazi veći broj rekvizita, a samim tim je i nastava interesantnija. Učenice su bile jednoglasne kada je u pitanju mjesto izvođenja nastave, a to je fiskulturna sala (100\%), kao i većina dječaka (82\%). Rezultati pokazuju da se u ovoj varijabli javlja statistički značajna razlika, takođe u korist djevojčica. Da bi se zaokružila slika o sveukupnom stavu učenika prema nastavi fizičkog vaspitanja koja se raalizuje u njihovoj školi, postavljeno je i poslednje pitanje u upitniku, koje se odnosilo na to šta bi promijenili učenici u nastavi ovog predmeta. Kako su prethodnim odgovorima izrazili zadovoljstvo nastavom fizičkog vaspitanja, tako su kod oba pola većina odgovora bila pozitivna, odnosno učenici (81\%) i učenice (89\%) su odovorili da ništa ne bi mijenjali u nastavi Fizičkog vaspitanja. Ipak jedan dio učenika (16\%) i učenica (9\%) bi uticao na promjenu programa iz ovog predmeta. Kao što se može vidjeti, opet su to u većem procentu dječaci, pa se to povezuje sa več navedenim ličnim afinitetima svakog pojedinca prema određenoj oblasti ili sportu, pa otuda i takvi odgovori.

Kada su u pitanju stavovi učenika prema fizičkom vaspitanju u mlađim razredima i prethodna istraživanja ukazuju da su tamo veoma zastupljeni pozitivni stavovi učenika (Arabaci, 2009; Atan \& Imamoglu, 2016) bez obzira na činjenicu da je većina časova realizovana neadekvatno ili čak nije ni realizovana. Što zbog ograničenih uslova kada su u pitanju prostor i rekviziti, što zbog ličnih afiniteta učitelja prema drugim predmetima. Međutim, učenici su bili svjesni važnosti fizičkog vaspitanja za integralni razvoj ličnosti (Bjelica, 1999a; Bjelica, 1999b; Bjelica, 2002; Radovanović, Madić, i Nikolić, 2003). Kako fizičko vaspitanje i sama fizička aktivnost van škole podsticajno djeluju na djecu, njihovu popularnost u društvu i način za druženje, sve to kod djece stvara pozitivne stavove o nastavi fizičkog vaspitanja (Švraka, 2012). Nije rijetkost da negativni stavovi kada su u pitanju rekviziti, oprema i prostor, obično rezulitiraju odlaskom sa časova Fizičkog vaspitanja i nezainteresovanošću za sami proces nastave (Pantović, 2017).

U skladu sa predhodnim, rezultati stavova ispitivanih učenika istog uzrasta prema nastavi fizičkog vaspitanja su takođe pozitivni. Ovakav zaključak se iznosi na osnovu datih odgovora da većina učenika voli časove fizičkog vaspitanja. Anketirani učenici pridaju veliki značaj nastavi fizičkog vaspitanja, a posebno njenoj funkciji, tj. njenom doprinosu zdravstvenom stanju i skladnoj građi tijela (Međedović i sar., 2005; Bjelica, 2006; Bjelica i Petković, 2009; Bjelica i Krivokapić, 2010).

Nakon primjene Hi kvadrat testa, upoređujući stavove dječaka i djevojčica, dobijeni rezultati ukazuju na to da postoje statistički značajne razlike u određenim stavovima učenika prema nastavi fizičkog vaspitanja s obzirom na pol. Razlike su se javili u varijablama za procjenu važnosti zdravog tijela, fizičkog vaspitanja kao i mjesta održavanja nastave fizičkog vaspitanja. Ipak, treba naglasiti da su procentualno razlike veoma male, ali se ipak javljaju. Bez obzira na te razlike, dječaci i djevojčice su približno isto odgovorili na svako od postavljenih pitanja, što nam jasno stavlja do znanja da više ne postoji razlika u zainteresovanosti u korist dječaka, kao što je nekada bio veoma čest slučaj (Višnjić, Martinović, Ilić, Marković, i 2010; Džibrić, Bašinac, Biberović, i Tuzović, 2014; Alić, 2017). Sada djevojčice pokazuju veću zainteresovanost za nastavu i pozitivne stavove, čemu je doprinijela pozitivna promjena u organi- zaciji nastave, odnosno uvažavanje različitosti između polova. Jasno je da dječaci i djevojčice preferiraju različite sportove, pa je tu potrebno naći balans između njihovih afiniteta, programa i sadržaja koji se nude kroz ovaj predmet.

Svrha ovog istraživanja bila je da se utvrde stavovi učenika IV razreda osnovne škole prema nastavi fizičkog vaspitanja, kao i to da li postoje razlike u stavovima istog uzrasta s obzirom na pol. Dobijeni rezultati ukazuju na to da postoje vrlo pozitivni stavovi učenika prema nastavi fizičkog vaspitanja, ali i da postoje statistički značajne razlike između nekih stavova s obzirom na pol i to u korist djevojčica.

Neka interesovanja mogu da budu signal asocijalnih i kontrasocijalnih tendencija, što takođe predstavlja dobru osnovu za izgrađivanje adekvatne strategije uticaja. Programi fizičkog vaspitanja u školi, u budućnosti, sve više trebaju se zasnivati na stvarnim potrebama učenika, njegovim osobinama, sposobnostima i interesima. Jedno od osnovnih pitanja u nastavi fizičkog vaspitanja, jeste pitanje cilja i zadataka. U tom pogledu Fizičko vaspitanje mora se bazirati na sve izgrađenijim potrebama i interesima učenika za obogaćivanjem i osmišljavanjem programa. Zbog toga je značaj rezultata koji su dobijeni ovim istraživanjem upravo praktične prirode. Interesovanja učenika mogu da budu značajan indikator njihovih potreba, želja, afiniteta. To može da predstavlja osnovu za planiranje sadržaja koji se nude mladima u školi i van nje. Sve razloge pozitivnog i negativnog doživljaja časa fizičkog vaspitanja treba iskoristiti sa namjerom da se poboljša kvalitet nastave. Radova na ovu temu nema puno i potrebna su dalja istraživanja da bi se detaljno upoznali sa problemima u nastavi fizičkog vaspitanja kao i pronalaskom rješenja za njihovo prevazilaženje.

\section{Acknowledgements}

There are no acknowledgements.

\section{Conflict of Interest}

The authors declare that there are no conflicts of interest.

Received: 5 November 2018 | Accepted: 16 December 2018 | Published: 25 January 2019

\section{References}

Alic, J. (2017). Gender Differences in Goal Orientation between High School Students in Physical Education Classes. Croatian Journal of Education, 19(Sp.Ed.No.2), 171-188.

Arabaci, R. (2009). Attitudes toward physical education and class preferences of Turkish secondary and high school students. Elementary Education Online, 8(1),2-8.

Atan, T., \& Imamoglu, M. (2016). Attitudes of secondary school students towards physical education and sports lesson in terms of various variables. Turkish Journal of Sport and Exercise, 18(2),65-68.

Bjelica, D. (1999a). Stavovi učenika osmih razreda osnovnih škola Crne Gore prema nastavi Fizičkog vaspitanja. Fizička kultura, 1, 78-80.

Bjelica, D. (1999b). Stavovi učenika osmih razreda osnovnih škola Crne Gore prema nastavi Fizičkog vaspitanja. Polis, 28 (1666), 48.

Bjelica, D. (2002). Stavovi učenika osmih razreda osnovnih škola u Crnoj Gori prema nastavnim i vannastavnim aktivnostima fizičkog vaspitanja. Čanj: Ljetnja škola pedagoga fizičke kulture.

Bjelica, D. (2006). Teorijske osnove tjelesnog i zdrastvenog obrazovanja. Podgorica: Crnogorska sportska akademija.

Bjelica, D., \& Petkovic, J. (2009). Teorija fizičkog vaspitanja i osnove školskog sporta. Podgorica: Crnogorska sportska akademija.

Bjelica, D., i Krivokapić, D. (2010). Teorijske osnove fizičke kulture. Nikšić: Fakultet za sport i fizičko vaspitanje Univerziteta Crne Gore.

Branković, D. i llić, M. (2003). Osnovi pedagogije. Banja Luka: Comesgrafika.

Đorđić, V. (2006): Žene i sport. U G. Bala (Ur.): Fizička aktivnost devojčica i dečaka predškolskog uzrasta (13-31). Novi Sad: Fakultet fizičke kulture.

Đorđić, V. i Tumin, D. (2008): Da li su devojčice „problem“ u nastavi fizičkog vaspitanja. Pedagogija, 63(4), 652-665.

Dzibric, D., Dedic, V., \& Bojic, A. (2011). Differences in preferences towards sport activity in primary school students. Sport Mont, 9(31-32-33), 31-35. 
Džibrić, Dž., Bašinac, I., Biberović, A. i Tuzović, A. (2014). Razlike u stavovima srednjoškolaca prema fizičkom vaspitanju. U Zborniku radova $X$ međunarodne konferencije "Izazovi savremenog menađmenta u sportu (95-100). Beograd: Alfa univerzitet-Fakultet za menadžment u sportu, Sarajevo: Fakultet sporta i tjelesnog odgoja.

Jovanović, B. (1998). Škola i vaspitanje. Jagodina: Učiteljski fakultet.

Međedović, E., Murić, B. i Međedović, A. (2005). Stavovi učenika četvrtih razreda osnovnih škola prema nastavi fizičkog vaspitanja. U Zbornik radova XI Nacionalnog naučnog skupa sa međunarodnim učešćem "Fis komunikacije 2005" (92-99). Niš: Fakultet fizičke kulture.

Mišigoj-Duraković, M. (1999). Tjelesno vježbanje i zdravlje. Zagreb: Fakultet za fizičku kulturu.

Pantović, M. (2017). Zašto učenici (ne) vole nastavu fizičkog vaspitanja. Master rad, Novi Sad: Fakultet sporta i fizičkog vaspitanja.

Pennington, D.C. (1997). Osnove socijalne psihologije. Jastrebarsko: Naklada Slap.
Radovanović, Đ., Madić, D. i Nikolić, M. (2003). Mišljenje učenika petog razreda o nastavi fizičkog vaspitanja u mlađim razredima osnovne škole. U Zbornik radova $X$ Nacionalnog naučnog skupa sa međunarodnim učešćem "Fis komunikacije 2003" (90-3). Niš: Fakultet fizičke kulture.

Rot, N. (1983). Osnove socijalne psihologije. Beograd: Zavod za udžbenike nastavna sredstva

Rowland, T.W. (1999): Adolescence: A „risk factor" for physical inactivity. President's Council on Physical Fitness and Sports, 3(6), 1-8.

Švraka, N. (2012). Stavovi mlađeg školskog uzrasta o pripadnosti grupi u nastavi fizičkog vaspitanja. SVAROG, 4, 294 - 302.

Vidić, T. (2016). Stavovi učenika osnovne škole prema Matematici. Napredak, $157(1-2), 11-32$.

Višnjić, D., Martinović, D., Ilić, J. i Markovič, Ž. (2010). Ispitivanje relacija postignuća i motivisanosti učenika VII razreda za angažovanje u nastavi fizičkog vaspitanja. Sport Mont, 8(23-24), 242-7. 